\title{
Progressive Myoclonic Epilepsy and NEU1 Mutation: A Different Phenotypic Case
}

\author{
Progresif Miyoklonik Epilepsi ve NEU1 Mutasyonu: Farklı Bir Fenotipik Olgu
}

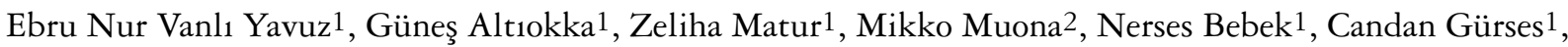 \\ Anna Elina Lehesjoki ${ }^{2}$, Ayşen Gökyiğit ${ }^{1}$, Betül Baykan ${ }^{1}$ \\ 1 İstanbul University İstanbul Faculty of Medicine, Department of Neurology, Clinical Neurophysiology Unit, İstanbul, Turkey \\ 2University of Helsinki Faculty of Medicine, Institute for Molecular Medicine Finland, Helsinki, Finland
}

\section{Summary}

Sialidosis are autosomal recessive inherited disorders caused by a mutation on the NEU1 gene. In type 1 sialidosis, a "cherry-red spot" can be observed in fundoscopic examinations. In this study, a woman aged 37 years without "cherry-red spot" on ophthalmologic examination is reported to draw attention to a new phenotypic variation. Although an ophthalmologic examination was normal, for patients with consanguineous parents with progressive ataxia, drug-resistant epilepsy and myoclonus must be investigated for progressive myoclonic epilepsy and genetic analysis for sialidosis must be performed. The diagnosis is also crucial for genetic consultancy of the family.

Keywords: Progressive myoclonic epilepsy, sialidosis, NEU1 gene mutation, cherry-red spot

\section{$\ddot{O} z$}

Siyalidozlar, NEU1 geninde mutasyon sonucu gelişen otozomal resesif geçişli bir grup lizozomal depo hastalığıdır. Tip 1 siyalidozda tipik olarak fundus muayenesinde "cherry-red spot" görülür. Bu çalışmada "cherry-red spot” bulgusu olmadığı halde genetik incelemeler sonrasında NEU1 mutasyonu saptanan 37 yaşında kadın olgu, siyalidoz tablolarındaki fenotipik çeşitliliğe dikkat çekmek amacıyla sunulmuştur. Anne baba akrabalığı olan, ilerleyici ataksi, dirençli epilepsi ve miyoklonileri olan hastalarda progresif miyoklonik epilepsiler yönünden diğer etiyolojilerin yanı sıra fundus muayenesi normal olmasına rağmen siyalidoz da genetik açıdan araştırılmalıdır. Doğru tanı aileye danışmanlık verilmesi açısından önemlidir.

Anahtar Kelimeler: Progresif miyoklonik epilepsi, siyalidoz, NEU1 gen mutasyonu, cherry-red spot

\section{Introduction}

Sialidosis, which is among the rare causes of progressive myoclonic epilepsy (PME), involves a deficiency in the activity of lysosomal neuroaminidase 1 (NEU1) enzyme. It is an autosomal recessive lysosomal storage disease caused by a mutation in the NEU1 gene. It is divided into two groups depending on the onset of disease and clinical findings. Type 1 sialidosis has a relatively late onset. Its course is relatively benign, dysmorphic features are absent, ataxia, myoclonus, and seizures are present, and typically a "cherry-red spot" is seen in an examination of the fundus $(1,2)$.
In type 2 disease with infantile onset, dysmorphic features, organomegaly, and severe mental retardation are seen. To date, 42 mutations that cause sialidosis have been reported on the NEU1 gene, which is located on the $6 \mathrm{p} 21.6$ locus of the $6^{\text {th }}$ chromosome, and these mutations cause genetic heterogeneity $(3,4)$.

We present a patient who had slowly progressive ataxia comorbid with refractory epilepsy and myoclonus. Her parents were $3^{\text {rd }}$ degree relatives. Although she had been diagnosed as having PME for years, a true etiologic diagnosis could not be made due to the absence of a "cherry-red spot"; however, a genetic evaluation revealed NEU1 mutation. We present this case to

Address for Correspondence/Yazışma Adresi: Ebru Nur Vanlı Yavuz MD, İstanbul University İstanbul Faculty of Medicine, Department of Neurology, Clinical Neurophysiology Unit, İstanbul, Turkey

Phone: +902124142000 E-mail: ebruvanli@hotmail.com

Received/Geliş Tarihi: 15.10.2014 Accepted/Kabul Tarihi: 18.01.2015 
highlight the phenotypic variability in the clinical presentation of sialidoses.

\section{Case Report}

A woman aged 37 years from Siverek, Şanlıurfa, presented with symptoms of bilateral whole body tremor, jerks, and imbalance, which was prominent in the left hand, especially in the mornings. The symptoms first started when she was seventeen and generalized tonic-clonic seizures (GTCS) began in the same year. Her convulsions were triggered during periods of excitation and tremor also increased. Despite treatment with valproic acid, clonazepam, pyrimidone, and piracetam, the seizures repeated at least once a month. Speech disorder and forgetfulness joined these symptoms after 3-4 years. There was nothing significant in her medical history except two falls without loss of consciousness. Her family history revealed that her parents were $3^{\text {rd }}$ degree relatives and her cousin, who was aged 6 years, a history of GTCS without accompanying tremor or jerks that started after a fall. Her neurologic examination revealed dysarthric speech, ataxia, and positive and negative myoclonus in extremities, which were generalized, synchronized, and augmented with action. She stood up with bilateral support, myoclonus increased when she stepped forward, and after a few steps she tended to fall due to negative myoclonus. Her mental status was within normal limits and she succeeded in university entrance exams. Anamnesis and physical examination findings suggested PME and etiologic assessments were performed. The differential diagnosis included UnverrichtLundborg disease, Lafora disease, myoclonic epilepsy with raggedred fibers, sialidosis, neuronal ceroid lipofuscinosis and celiac disease. A skin biopsy, which was evaluated twice, muscle biopsy, ophthalmic examination, duodenal biopsy, detailed biochemical analyses, and lactate value were normal and antigliadin antibodies were negative. Electroencephalograph (EEG) evaluation revealed mild and general disorder in organization, prominent in the anterior half of the hemispheres, and hypersynchronization in the vertex. Neuropsychologic evaluation revealed impairments in executive function (frontal signs) such as increase in interference time, deficiency in category formation and changing, perseverations and decrease in mental flexibility. Cranial magnetic resonance imaging (MRI) showed cerebral and cerebellar atrophy. Back-averaging was used for the neurophysiologic evaluation and approximately 20-ms discharges priming myocloni were observed in the contralateral brain hemisphere triggered by potentials recorded from superficial electrodes that were located on the left forearm extensor muscles. Median somatosensory-evoked potential (SEP) evaluation revealed bilateral giant cortical responses $(>20$ $\mu \mathrm{V})$. With right median nerve stimulation, a moderate latency $\mathrm{C}$ reflex was recorded from the right thenar muscles. With doublestimulus transcranial magnetic stimulation no inhibitory response (which is expected under normal conditions) was seen after the $2^{\text {nd }}$ stimulus at 100 -ms interstimulus intervals. Nervous conduction, visual evoked potentials, and tibial SEP evaluations were within normal limits. The electrophysiologic findings of the patient are summarized in Figure 1. Although photosensitivity and typical generalized epileptiform activity were not observed, UnverrichtLundborg disease was considered depending on the clinical features but genetic evaluations demonstrated a normal-sized cystathionine
$\mathrm{B}$ gene promoter region, and an increase in dodecamer repeat numbers or point mutations were not detected. SCARB2 gene was evaluated for autosomal recessive cerebellar ataxias because of the severe body ataxia and the result was negative. Laforin and Malin genes were evaluated despite absence of Lafora bodies in the skin biopsy, relatively mild course, and lack of prominent mental findings; no mutation was detected. Although the ophthalmologic evaluation was within normal limits, a NEU1 mutation leading to c. $914 \mathrm{G}>\mathrm{A}$ and $\mathrm{c} 625 \mathrm{delG}$ protein variation was detected in the genetic evaluation, which was performed in Finland (5). A change in c625delG was previously defined in the same codon and was reported as pathogenic (6). However, the c.914G $>A$ that we detected in the same codon has not been previously reported to be pathogenic (7). Repeated ophthalmologic evaluation confirmed absence of "cherry-red spot". The patient, who had been followed up in our clinic for 14 years, was restricted to a wheelchair because of severe ataxia. GTCS declined in the last year after zonisamide $200 \mathrm{mg} /$ day was added to her treatment, which previously comprised valproic acid $1500 \mathrm{mg} /$ day, levetiracetam $2000 \mathrm{mg} /$ day, and clonazepam $4 \mathrm{mg} /$ day.

\section{Discussion}

PME is a rare group of genetic, symptomatic, and generalized epilepsies. Myoclonic seizures, GTCS, progressive neurologic findings, ataxia, and dementia are seen in patients with PME. The differential diagnosis is performed depending on age of onset, accompanying symptoms, cerebellar signs, and presence
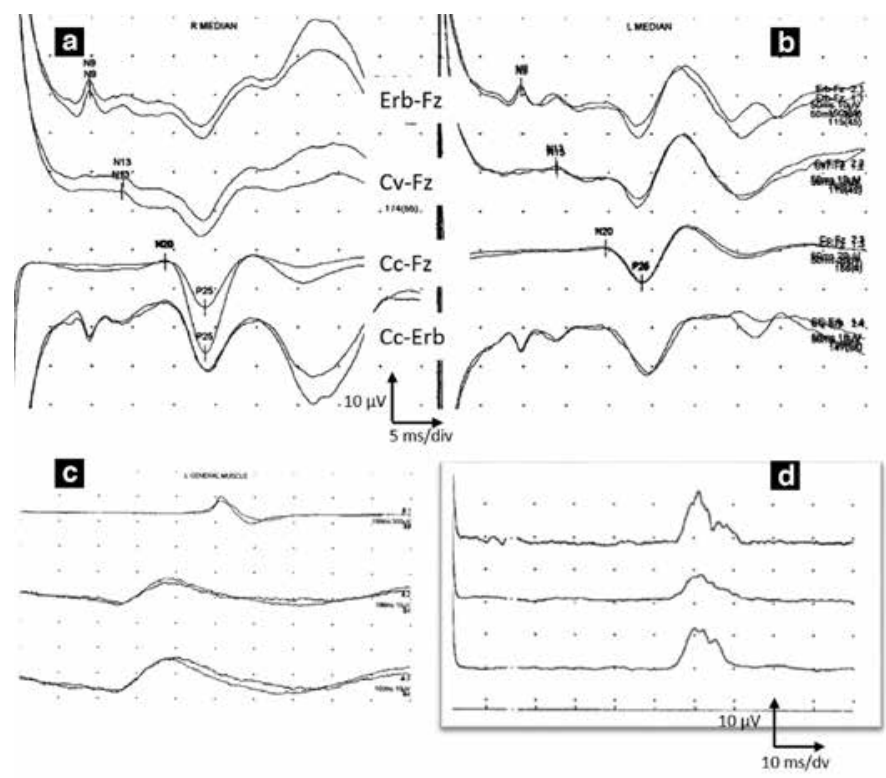

Figure 1. Electrophysiologic findings. Somatosensory-evoked potential responses obtained by stimulation of (a) right and (b) left median nerves at the wrist level. Giant cortical potentials $(>20 \mu \mathrm{V})$; contralateral brain hemispheric discharges which prime myocloni for approximately 20 ms triggered by potentials recorded with superficial electrodes located over the left forearm using back averaging (c); $\mathrm{C}$ reflex recorded with approximately $55 \mathrm{~ms}$ latency from right thenar muscles after right median nerve stimulation $(\mathrm{d})$ 
of dementia but a definite diagnosis is difficult due to variability of etiologies and phenotypes (8). Sialidoses are very rare diseases that are listed in PME etiologies, and diagnosis is usually made by genetic confirmation after observation of elevated urinary sialic acid or by demonstration of neuraminidase enzyme defect in fibroblast cultures $(6,9)$. They are usually missed in patients with PME who lack typical clinical findings and "cherry-red spot". Nevertheless, we detected a mutation in the NEU1 gene in our patient.

Myoclonus in these patients limits activities of daily life after progression of disease, and may cause injuries due to falls (8). Although hypothesis of gamma-aminobutyric acid dysfunction in inhibitory interneurons was proposed, mechanism of action myoclonus in PME forms has not yet been clearly understood. A study by Canafoglia et al. (9) showed more cortical irregularity in patients with sialidosis compared with patients with UnverrichtLundborg disease. Presence of giant SEP waves, cortical potentials priming myocloni seen with back-averaging, $\mathrm{C}$ reflex, and decreased cortical inhibition with double-stimuli transcranial magnetic stimulation evaluation suggested these myocloni to be cortically originated. Moreover, although cranial MRI may be normal at an early period, and repeated MRIs show diffuse cortical atrophy, just like in our patient (10). PMEs may clinically resemble juvenile myoclonic epilepsy and with EEG findings, but treatment refractoriness, progressive neurologic and EEG findings lead to PME diagnosis. A basic activity consisting of fast rhythms may be seen in EEG, but slowing is more prominent in patients with dementia (8). Our patient also had mild slowing in EEG during her follow up for 14 years and neuropsychologic findings that supported mild dementia in recent years.

Treatment generally aims to stop seizures and myoclonus. Antiepileptic medications used to control myocloni are combinations of valproic acid, benzodiazepines, phenobarbital, piracetam, zonisamide, and levetiracetam. The effects of these drugs on myoclonus increase during the first 12 months and then stay steady. Additionally, drugs that increase myoclonus such as vigabatrine, carbamazepine, phenytoin, and gabapentin should be avoided. In the future, new management strategies such as gene treatment and enzyme replacement therapies are promising possible treatments $(11,12)$. Our patient's seizures were also controlled during the last year after with the addition of zonisamide to her treatment regime. Fundoscopic examination is important in patients who develop ataxia in the early ages. A "cherry-red spot" or perifoveal white patch can be detected in the fundoscopic examination. Although this phenomenon is a classic finding for sialidosis, it may also be seen in GM1 gangliosidosis, hexoseaminidase defect, and Nieman-Pick and Gaucher's disease (13). In addition, a few cases were reported in which a "cherryred spot" was not detected, despite the presence of a mutation in the NEU1 gene $(6,9)$. We also could not detect "cherry-red spot" despite the presence of a NEU1 mutation; this documents the presence of a new phenotype in our country.

\section{Conclusion}

In conclusion, all evaluations for PMEs should be made in patients with progressive ataxia, refractory epilepsy, and myoclonus. A genetic evaluation should be performed in patients with sialidosis whose clinical and electrophysiologic findings suggest PME, despite normal fundoscopic evaluation. Diagnosis is important for this rare form of hereditary sialidosis for which gene treatments may be possible in the future.

\section{Ethics}

Informed Consent: Consent form was filled out by participant. Peer-review: Externally peer-reviewed.

\section{Autborship Contributions}

Medical Practices: Betül Baykan, Mikko Muona, Anna Elina Lehesjoki, Nerses Bebek, Candan Gürses, Aysen Gökyiğit, Concept: Ebru Nur Vanlı Yavuz, Betül Baykan, Design: Ebru Nur Vanlı Yavuz, Betül Baykan, Günes Altıokea, Data Collection or Processing: Ebru Nur Vanl Yavuz, Betül Baykan, Analysis or Interpretation: Ebru Nur Vanlı Yavuz, Betül Baykan, Zeliha Matur, Literature Search: Ebru Nur Vanlı Yavuz, Günes Altıoke, Writing: Ebru Nur Vanlı Yavuz, Betül Baykan, Zeliba Matur.

Conflict of Interest: No conflict of interest was declared by the authors

Financial Disclosure: The authors declared that this study has received no financial support.

\section{References}

1. Ramachandran N, Girard JM, Turnbull J, Minassian BA. The autosomal recessively inherited progressive myoclonus epilepsies and their genes. Epilepsia 2009;50 (Suppl 5):29-36.

2. Lai SC, Chen RS, Wu Chou YH, Chang HC, Kao LY, Huang YZ, Weng YH, Chen JK, Hwu WL, Lu CS. A longitudinal study of Taiwanese sialidosis type 1: An insight into the concept of cherry-red spot myoclonus syndrome. Eur J Neurol 2009;16:912-919.

3. Caciotti A, Di Rocco M, Filocamo M, Grossi S, Traverso F, d'Azzo A, Cavicchi C, Messeri A, Guerrini R, Zammarchi E, Donati MA, Morrone A. Type II sialidosis: Review of the clinical spectrum and identification of a new splicing defect with chitotriosidase assessment in two patients. J Neurol 2009;256:1911-1915.

4. Chen CM, Lai SC, Chen IC, Hsu KC, Lyu RK, Ro LS, Chang HS. First report of two Taiwanese siblings with sialidosis type I: A 10-year follow-up study. J Neurol Sci 2006;247:65-69.

5. Muona M, Berkovic SF, Dibbens LM, Oliver KL, Maljevic S, Bayly MA, Joensuu T, Canafoglia L, Franceschetti S, Michelucci R, Markkinen S, Heron SE, Hildebrand MS, Andermann E, Andermann F, Gambardella A, Tinuper P, Licchetta L, Scheffer IE, Criscuolo C, Filla A, Ferlazzo E, Ahmad J, Ahmad A, Baykan B, Said E, Topcu M, Riguzzi P, King MD, Ozkara C, Andrade DM, Engelsen BA, Crespel A, Lindenau M, Lohmann E, Saletti V, Massano J, Privitera M, Espay AJ, Kauffmann B, Duchowny M, Møller RS, Straussberg R, Afawi Z, Ben-Zeev B, Samocha KE, Daly MJ, Petrou S, Lerche H, Palotie A, Lehesjoki AE. A recurrent de novo mutation in $\mathrm{KCNC1}$ causes progressive myoclonus epilepsy. Nat Genet 2015;47:39-46.

6. Lukong KE, Elsliger MA, Chang Y, Richard C, Thomas G, Carey W, TylkiSzymanska A, Czartoryska B, Buchholz T, Criado GR, Palmeri S, Pshezhetsky AV. Characterization of the sialidase molecular defects in sialidosis patients suggests the structural organization of the lysosomal multienzyme complex. Hum Mol Genet 2000;9:1075-1085.

7. Canafoglia L, Robbiano A, Pareyson D, Panzica F, Nanetti L, Giovagnoli AR, Venerando A, Gellera C, Franceschetti S, Zara F. Expanding sialidosis spectrum by genome-wide screening: NEU1 mutations in adult-onset myoclonus. Neurology 2014;82:2003-2006.

8. Shahwan A Farrell M, Delanty N. Progressive myoclonic epilepsies: A review of genetic and therapeutic aspects. Lancet Neurol 2005;4:239-248.

9. Canafoglia L, Franceschetti S, Uziel G, Ciano C, Scaioli V, Guerrini R, Visani E, Panzica F. Characterization of severe action myoclonus in sialidoses. Epilepsy Res 2011;94:86-93. 
10. Sekijima Y, Nakamura K, Kishida D, Narita A, Adachi K, Ohno K, Nanba E, Ikeda S. Clinical and serial MRI findings of a sialidosis type I patient with a novel missense mutation in the NEU1 gene. Intern Med 2013;52:119-124.

11. Roivainen R, Karvonen MK, Puumala T. Seizure control in UnverrichtLundborg disease: A single-centre study. Epileptic Disord 2014;16:191-195.
12. Striano P, Belcastro V. Treatment of myoclonic seizures. Expert Rev Neurother 2012;12:1411-1417.

13. Vieira de Rezende Pinto WB, Sgobbi de Souza PV, Pedroso JL, Barsottini OG. Variable phenotype and severity of sialidosis expressed in two siblings presenting with ataxia and macular cherry-red spots. J Clin Neurosci 2013;20:1327-1328. 